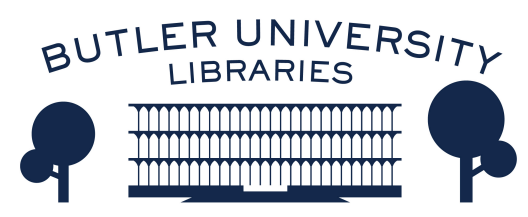

Journal of Hindu-Christian Studies

\title{
Book Review: "Protestant Origins in India: Tamil Evangelical Christians, 1706-1835"
}

Francis X. Clooney

Follow this and additional works at: https://digitalcommons.butler.edu/jhcs

Part of the Religion Commons

\section{Recommended Citation}

Clooney, Francis X. (2001) "Book Review: "Protestant Origins in India: Tamil Evangelical Christians, 1706-1835"," Journal of Hindu-Christian Studies: Vol. 14, Article 18.

Available at: https://doi.org/10.7825/2164-6279.1261

The Journal of Hindu-Christian Studies is a publication of the Society for Hindu-Christian Studies. The digital version is made available by Digital Commons @ Butler University. For questions about the Journal or the Society, please contact cbauman@butler.edu. For more information about Digital Commons @ Butler University, please contact digitalscholarship@butler.edu. 
and the fire are not seen," writes Coward, "it takes an act of imagination to connect what is happening inside the closed casket and high-tech furnace with the reintegration of the person's body/soul with the divine cosmos through the bright fire of the god Agni. The ritual loses some of its immediate symbolic power to interpret death as moving from the transience of the body to the unity of all creation in the Divine." Kim Knott reminds us of the new demands made on the Hindu tradition in Britain by youths requiring English-medium instructional materials, leadership opportunities, ethical engagement and more public responsibilities for women.

The journey of South Asian religious traditions in the United States, Canada and Britain, while historically young, is of tremendous significance, not only for these countries, but also for the development of these religions in the old country. In an era of globalization, change and transformation in the diaspora will eventually affect the meaning and practice in their places of origin. The direction of influence will not only flow from the old to the new. In this work, a group of distinguished scholars have commenced the work of noting the historical landmarks in this journey and of identifying and commenting on the issues which are and which will grow in significance as the journey continues. With this work, we will hopefully see more attention given to the study of South Asian traditions in their western homes along with the more traditional courses devoted to textual and doctrinal developments in Asia.

Anantanand Rambachan Saint Olaf College

\section{Protestant Origins in India: Tamil Evangelical Christians, 1706-} 1835. D. Dennis Hudson. Grand Rapids: William B. Eerdmans Publishing Company; Richmond (UK): Curzon Press, Ltd., 2000, xi +220 pp.

THIS FINE VOLUME complements Daniel Jeyaraj's Inkulturation in Tranquebar (Erlangen: Verlag der Ev.-Luth. Mission, 1996; reviewed in this Bulletin in 1999), and Brijraj Singh's The First Protestant Missionary to India: Bartholomaeus Ziegenbalg 1683-1719 (New Delhi: Oxford University Press, 1999). Like Yeyaraj and Singh, Hudson begins his account with Ziegenbalg and the early $18^{\text {th }}$ century Protestant mission in Travancore, which was a Dutch East India trading post in the Tanjore district of Tamil Nadu. Hudson's work particularly complements that of Jeyaraj, while developing the theme with a closer focus on fresh biographical materials. On the whole, Hudson is less interested in the European missionaries and more interested in the indigenous Christian community, the nature of the emerging Protestant - Evangelical - Tamil Christian community.
Hudson is acutely and expertly aware throughout of the ways in which Tamil culture, language and religion shaped the particular kind of Christian identity. As he states in the preface, certain traditional questions came to life for the first Protestant converts in Tamil Nadu: "To what had they converted when German Pietist Lutherans baptized them in the Danish colony of Tranquebar? Was it a style of living that prescribed certain foods and certain modes of social behaviour, as was true for the Muslims of India, or was it something else? What did it mean to follow the command, 'Love you neighbor as yourself', and who was to decide?" (p. x) Since Hudson is wellversed in Tamil studies, he brings a sophisticated and multi-faceted sensitivity to the material, highlighting the different representations of religion and culture put forward by Christian and Hindu, Indian and foreigner, alike. 
Vivid individual figures stand out: Aaron (1698-1745), who was the first ordained Tamil pastor and who had been born Arumugan Pillai in a Saiva Velala family; Rajanayakan (1700-1771), who had been a Roman Catholic catechist before becoming an Evangelical' Vedanayagam Pillai (1774-1864), a convert who served as headmaster in a "scripture school" (sastrapalli) for 35 years. These stories are interesting in themselves, but Hudson puts them to excellent use in locating issues within the Evangelical Protestant community and in the culture at large. Dandapani Swami (1839-1898) was a Saiva Velala devotee of Lord Murukan who did not convert to Christianity. Hudson reviews his treatise, Sattiya Suttirum ("Scripture of Truth") in order to offer a thoughtful Hindu view of Tamil culture and religion, which stands in illuminating contrast with the views of convert and missionary. While Hudson's effort to see the issues from all sides cannot be entirely successful - the materials necessary for such a project seem not to be available - his analysis is much more richly multidimensional than such studies normally are.

Protestant Origins also explores changing attitudes in the community, particularly when, in the generations after Ziegenbalg, "new missionaries" brought with them to India strict and unyielding views of : Christian identity and distinctiveness. Some missionaries and some Tamil Christians found it problematic that there was so great a residue of Hindu and Roman Catholic influence in the liturgy, yet efforts to "purify" Tamil Christianity also alienated many who had already made adjustments in keeping with their own needs. Thus there are heated arguments in the Christian community about Bible translation, the proper list of Christian festivities, the use of exclusion of customary Tamil music and songs in worship, and the maintenance of caste, with various missionaries and Tamil Christians taking different sides.
Protestant Origins is an important study in the phenomenon of conversion and church community formation, and it enables us to understand more clearly what becoming a Christian meant in colonial India. Since the converts' story rightly occupies the central place in the account, it is a refreshing contribution to mission studies, which are often restricted to accounts of the deeds and words of Western missionaries. As a study in Protestant mission, it can be interestingly compared with studies in Roman Catholic mission, such as Augustin Saulière's biography of the $17^{\text {th }}$ century Jesuit missionary Roberto de Nobili, His Stor in the East (Madras: de Nobili Research Institute, 1995), and also Ines Zupanov's Disputed Mission: Jesuit Experiments and Brahmanical Knowledge in Seventeenth-Century India (Delhi: Oxford University Press, 1999), a study of the arguments about missionary strategy between de Nobili and his contemporary, Gonçalo Fernandes, S.J. (On Saulière's and Zupanov's books, see the 2000 issue of this Bulletin). What is really needed, though, is further detailed study, preferably by Hindu scholars, of Hindu reactions to the missionaries and converts to Christianity in pre-Independence India. While Sita Ram Goel's History of Hindu-Christian encounters (AD 304 to 1996) is an important beginning of such a review, much more work remains to be done by Hindu scholars.

What do we learn from Hudson's book that is particularly pertinent to HinduChristian studies? In part, it confirms the expected. Conversion may be a personal choice in many cases, but it is not a private event. Whole communities' opinions and values come into play, and of course both the Vaisnava and Saiva traditions, and Christian churches, are complex institutions which command people's allegiances in differing ways on differing explicit and implicit levels. Perhaps Hudson's greatest service is to remind us that there was no golden age or entirely wicked epoch of conversions, and that the past does not differ entirely from the present. Today's 
controversies have a long history in which

both Indians and Europeans have participated vigorously.

Francis X. Clooney, S.J. Boston College

\section{Finding Jesus in Dharma: Christianity in India. Chaturvedi.} Badrinath. ISPCK: Delhi, 2000, xii +217 pp.

THE HISTORY of the encounter between Christianity and Hinduism is a fascinating yet frustrating project due to the complexity of both religious traditions and their respective histories. Chaturvedi Badrinath, a Hindu philosopher and thinker, offers in this book a penetrating analysis of this encounter, which both broadens and deepens our understandings of both traditions. Since his analysis takes Jesus and Dharma as its operative categories, the book opens by stating, "For me, Jesus Christ is the perfect embodiment of dharma." (p.1). Badrinath offers a way to understand what dharma stands for by looking at its three attributes: prabhava, dharana and a-himsa. Thus dharma is that which is nurturing life, supporting all living beings, and securing freedom from violence. Given such a view of dharma, the author goes on to claim that the encounter between Christianity and Hinduism in India is the interaction between "a deep sense of Hindu reverence for Jesus" and "an equally deep rejection of missionary arrogance." (p.3). The rest of the book is the unfolding or unpacking of this claim.

The author begins with a very brief summary of Christianity. He acknowledges that the abstract view of Christianity he offers is not an invitation to forget neither the manifestation of Christian faith in social practice, nor that the ideas of Christianity are dependent on the relationship between church and state. This means that "Christianity is the history of the Church." (p.7). Then follows an examination of the encounter between the Syrian Orthodox tradition and the Dharmic communities of India, and the meeting of Catholicism and
Hinduism. The author finds that the Syrian Orthodox tradition in India has more successfully accommodated itself into the Dharmic ordering of life in India than any of the other Christian traditions in India. The next three chapters deal specifically with the encounter between Protestant Christianity and the Dharmic communities. They outline two types of Christianity, viz., an abusive Christianity that tragically fails to understand the Hindu mind and life, and a sympathetic Christianity that, in spite of its good intentions, fails to grasp the core of what it means to live in a Dharmic society. Badrinath highlights some of the failures of Christianity in dealing with matters such as caste and image worship. $\mathrm{He}$ also exposes both the problems and complexities in attempts at self-governance of the Christian church in India and the processes of indigenisation of the Christian faith within the Indian and Dharmic setting.

While the earlier chapters focussed attention on what Western missionaries in India thought and wrote, the seventh chapter shifts attention to Indian Christian theologians of the $19^{\text {th }}$ and $20^{\text {th }}$ centuries who attempted to interpret Christianity in Hindu terms. The theologians considered in this chapter include Goreh, Chenchiah, $M$. Thomas, Raimon Panikkar and Paulos Mar Gregorios. From this Badrinath concludes that: "Christianity would mean little to India unless expressed in Dharmic idiom; but that idiom is so alien to the temper of historical Christianity, and so indefinite in itself, that its use is best calculated to neutralise whatever is distinctive in Christianity." (p.110). In the following chapter, the author 